\title{
Assessment of the mutagenic, antimutagenic and cytotoxic activities of ethanolic extract of araticum (Annona crassiflora Mart. 1841) by micronucleus test in mice
}

\author{
Vilar, JB. ${ }^{\mathrm{a}}$, Ferreira, FL. ${ }^{\mathrm{a}}$, Ferri, $P H .{ }^{\mathrm{b}}$, Guillo, $L A .{ }^{\mathrm{c}}$ and Chen Chen, $L .^{\mathrm{a} *}$ \\ ${ }^{a}$ Departamento de Biologia Geral, Instituto de Ciências Biológicas, Campus - II, Universidade Federal de Goiás - UFG, \\ CEP 74001-970, CP 131, Goiânia, GO, Brazil

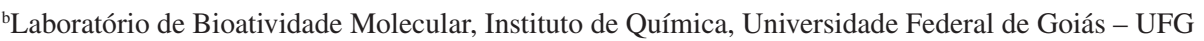 \\ 'Departamento de Ciências Fisiológicas, Instituto de Ciências Biológicas, Campus II, \\ Universidade Federal de Goiás - UFG, CEP 74001-970 Goiânia, GO, Brazil \\ *e-mail: chenlee@icb.ufg.br \\ Received February 9, 2006 - Accepted May 16, 2006 - Distributed February 29, 2008
}

\begin{abstract}
A typical Brazilian plant, araticum (Annona crassiflora Mart.), is widely used in humans as therapeutic medicine to treat several diseases such as diarrhea, rheumatism and syphilis. It contains acetogenins which present cytotoxic, antitumogenic, and antiparasitic properties. In this study, mutagenic, antimutagenic and cytotoxic effects of araticum leaves ethanolic extract were evaluated by micronucleus test in mice. To evaluate the mutagenic activity, animals were treated with ethanolic extract of araticum (EEA) using 10, 20, 50, 100 and $160 \mathrm{mg} \cdot \mathrm{kg}^{-1}$. For all doses, micronucleated polychromatic erythrocytes (MNPCE) frequency was evaluated at 24, 48 and 72 hours after treatment. To evaluate the antimutagenic activity, animals were treated with 10, 20, 50 and $100 \mathrm{mg} \cdot \mathrm{kg}^{-1}$ of EEA and $4 \mathrm{mg} \cdot \mathrm{kg}^{-1}$ of MMC simultaneously. The frequency of MNPCE was evaluated 36 hours after exposure. Cytotoxicity was evaluated by the polychromatic and normochromatic erythrocytes ratio (PCE/NCE). In the mutagenicity assessment, all doses of EEA resulted in no significant increase of MNPCE ( $>$ > 0.05), compared to solvent- control group. Regarding administration time, no significant difference among three evaluation periods was observed $(P>0.05)$. Such results indicate that EEA did not exert mutagenic activity. Cytotoxicity was evident in doses of 50, 100 and $160 \mathrm{mg} \cdot \mathrm{kg}^{-1}$ at 24 and 48 hours after exposure. Concerning antimutagenicity, except the $10 \mathrm{mg} \cdot \mathrm{kg}^{-1}$ co-administered with $4 \mathrm{mg} / \mathrm{kg}$ of MMC, all doses reduced significantly the frequency of MNPCE compared to the positive control group $(\mathrm{P}<0.05)$. These results, therefore, indicate an antimutagenic activity of the EEA. Cytotoxicity was significantly increased $(\mathrm{P}<0.01)$ at $100 \mathrm{mg} \cdot \mathrm{kg}^{-1}$ EEA doses co-administered with $4 \mathrm{mg} \cdot \mathrm{kg}^{-1}$ of MMC.

Keywords: Annona crassiflora, Araticum, Mutagenicity, Antimutagenicity, Cytotoxicity.
\end{abstract}

\section{Avaliação das atividades mutagênica, antimutagênica e citotóxica do extrato etanólico de araticum (Annona crassiflora Mart.) pelo teste de micronúcleos em camundongos}

\section{Resumo}

$\mathrm{O}$ araticum (Annona crassiflora Mart.) é uma planta tipicamente brasileira, largamente utilizada em humanos como remédio para o tratamento de diversas doenças como diarréia, reumatismo e sífilis. Esta planta contém acetogeninas que apresentam propriedades citotóxica, antitumorigênica e antiparasitária. Neste estudo, foram avaliados os possíveis efeitos mutagênico, antimutagênico e citotóxico do extrato etanólico de folhas de araticum, pelo teste de micronúcleos em camundongos. Para a investigação da atividade mutagênica, os animais foram tratados com o extrato etanólico de araticum (EEA) utilizando 10, 20, 50, 100 e $160 \mathrm{mg} \cdot \mathrm{kg}^{-1}$. Para todas as doses, as frequiências de eritrócidos policromáticos micronucleados (MNPCE) foram avaliadas em 24, 48 e 72 horas após o tratamento. Para a investigação da atividade antimutagênica, os animais foram tratados com 10, 20, 50 e $100 \mathrm{mg} \cdot \mathrm{kg}^{-1}$ de EEA simultaneamente com $4 \mathrm{mg} \cdot \mathrm{kg}^{-1}$ de MMC. A frequiência de MNPCE foi avaliada após 36 horas de exposição. A citotoxicidade foi avaliada pela razão de eritrócitos policromáticos e normocromáticos (PCE/NCE). Na avaliação da mutagenicidade, todas as doses de EEA não aumentaram significativamente o número de MNPCE $(\mathrm{P}>0,05)$, comparativamente as do grupo solvente-controle. Em relação ao tempo de administração, não foi constatada diferença significativa entre os 3 períodos avaliados $(P>0,05)$. Esses resultados indicam que o EEA não exerceu atividade mutagênica.A citotoxicidade foi evidente nas doses de 50, 100 e $160 \mathrm{mg} \cdot \mathrm{kg}^{-1} \mathrm{em} 24$ e 48 horas depois da exposição. Em relação à antimutagenicidade, exceto para a dose de $10 \mathrm{mg} \cdot \mathrm{kg}^{-1}$ co-administrada com $4 \mathrm{mg} \cdot \mathrm{kg}^{-1}$ de $\mathrm{MMC}$, todas reduziram significativamente a frequiência de MNPCE, comparativamente as do grupo controle positivo $(\mathrm{P}<0,05)$. Esses resultados, portanto, indi- 
cam uma atividade antimutagênica do EEA. A citotoxicidade foi significativamente aumentada $(\mathrm{P}<0,01)$ na dose de $100 \mathrm{mg} \cdot \mathrm{kg}^{-1}$ de EEA co-administrada com 4 mg. $\mathrm{kg}^{-1}$ de MMC.

Palavras-chave: Annona crassiflora, Araticum, Mutagenicidade, Antimutagenicidade, Citotoxicidade.

\section{Introduction}

Since ancient times, plants have always been used as a common source of medicines for their prophylactic effects and for the treatment of illnesses and diseases. The Brazilian flora has been estimated to be the largest in the world, the country being home to about 120 thousand species, of which only $1 \%$ have been studied for their phytochemical and pharmacological properties (Rizzo et al., 1996). It is often considered to be the most promising habitat for the search of medicinal plants, due to high biodiversity (Stepp, 2004). In conformity with this expectation, some plants have demonstrated interesting properties, such as Phaseolus vulgaris L., 1753 (Ribeiro and Salvatori, 2003), Croton cajucara Benth., 1854 (Serpeloni et al., 2004), Stryphnodendron adstringens (Mart.) Coville, 1910. (Andrade et al., 2004), that were able to reduce the incidence of DNA damage. However, others, such as Cochlospermum regium (Schrank) Pilg., 1924. (Castro et al., 2004), Ocotea duckei Vatt. (Marques et al., 2003), Paullinia cupana Kunth, 1821. (Fonseca et al., 1994), showed to be genotoxic and/or mutagenic, what suggest their use must be well established.

Even among the antimutagens, carefulness should also be taken. Many substances reported as antimutagens or anticarcinogens have been shown to be mutagenic or carcinogenic themselves (Zeiger, 2003). Plants are known to contain innumerable biologically active compounds and while they may have pharmacological properties, they may also cause damage, including damage to DNA (Alade and Irobi, 1993; Marques et al., 2003). In this way, the investigation of traditionally used medicinal plants is thus valuable on two levels: firstly, as a source of potential chemotherapeutic drugs, and secondly, as a measure of safety for the continued use of medicinal plants (Verschaeve et al., 2004).

Annona crassiflora Mart., 1841, popularly known as "Araticum", is a member of the Annonaceae family found in the central Cerrados of Brazil. The traditional use of this plant includes the treatment of wounds, venereal diseases, snakebites, louses and as anti-microbial, anti-diarrheal and anti-rheumatic (Almeida et al., 1987; Correia, 1926; Cruz, 1979). Cyathostemma Griff.,1854, Fissistigma oldhamii (Hemsl.) Merr., 1919, Annona cherimola Mill., 1768 and Annona senegalensis Pers., 1806, are annonaceous traditionally used ethnomedically against cancer (Graham et al., 2000).

A number of Annonaceae species of the genus Annona have been shown to contain polyketides with significant cytotoxic, antitumour, pesticidal, antimicrobial and antiparasitic activities (Rupprecht et al., 1990). The ethanolic extract of $A$. crassiflora seeds exhibited in vitro significant cytotoxicity to human lung carcinoma (A-549) and melanoma (RPMI 7951) cells. From this extract, an acetogenin (ACG - acetogenin) named araticulin was isolated (Santos et al., 1996). The biological effects of many annonaceous have been related to the ability of ACGs to inhibit the NADH: ubiquinone oxiredutase (complex 1) of the mitochondrial electron transport chain (González et al., 1998). This class of molecules has been suggested to be a group of potential anti-neoplastic agents (Alali et al., 1999; Yuan et al., 2003; Tormo et al., 1999). However, cytotoxicity could be associated with genotoxicity, as observed in many antitumoral substances of natural or synthetic origin. The presence of genotoxic action in antitumoral compounds does not benefit the organism in the long term (Ramos et al., 1998).

Due to the wide biological activities presented by this plant as well as the widespread use in folk medicine by Brazilian people, at the present study we have evaluated the mutagenic, antimutagenic and cytotoxic activities of Araticum's ethanolic extract by mouse bone marrow micronuclues test (Heddle, 1973).

\section{Materials and Methods}

\subsection{Animals}

Healthy, young male adults (8-12 weeks) Mus musculus (Swiss Webster) out bred mice, weighing 25-30 g, obtained from Central Animal House of Universidade Federal de Goiás, were used in the experiment. All animals were brought to the laboratory five days before the experiments. They were housed in plastic cages $(40 \times 30 \times 16 \mathrm{~cm})$ at $24 \pm 2{ }^{\circ} \mathrm{C}$ and $55 \pm 10 \%$ of humidity, with a light-dark natural cycle of 12 hours. Food (appropriate commercial ration- Labina, Ecibra Ltda) and water were given ad libitum.

\subsection{Plant material}

Leaves of A. crassiflora were collected in Paraúna, a town in the State of Goiás, Brazil, and identified by Professor Heleno Dias Ferreira (Departamento de Botânica, Instituto de Ciências Biológicas, Universidade Federal de Goiás). Air-dried and powdered leaves were exhaustively extracted with $95 \%$ aqueous ethanol at room temperature for three days. Alcohol solution was filtered and then concentrated under reduced pressure at $40{ }^{\circ} \mathrm{C}$ for dryness. The crude ethanolic extract was transferred to glass flasks filled to the top and kept at $5{ }^{\circ} \mathrm{C}$ until the moment of use. The powder of ethanolic extract of araticum (EEA - ethanolic extract of araticum) used 
in the experiment was dissolved in $25 \%$ ethanol-water solution.

\subsection{Chemical and drugs}

The chemical and drugs used in the experiment were the following: mitomycin $\mathrm{C}$ (MMC - mitomycin $\mathrm{C}$ ) $\left(\mathrm{C}_{15} \mathrm{H}_{18} \mathrm{~N}_{4} \mathrm{O}_{5}\right.$, Bristol-Myers Squibb, Lot No. 217ACB), Dibasic sodium phosphate $\left(\mathrm{Na}_{2} \mathrm{HPO}_{4} 12 \mathrm{H}_{2} \mathrm{O}\right.$, Merck, Lot No. 127H0168), Monobasic sodium phosphate $\left(\mathrm{NaH}_{2} \mathrm{PO}_{4} \mathrm{H}_{2} \mathrm{O}\right.$, Merck, Lot No. 47H1445), Giemsa (Doles, Lot No. 1081), Methanol $\left(\mathrm{CH}_{4} \mathrm{O}\right.$, Synth, Lot No. 39107), Fetal Calf Serum (Laborclin, Lot No. 30721063).

\subsection{Determination of LD (lethal dose)}

Ten-animal groups were treated intraperitonealy (i.p) with 100, 150, 250, 300, 400 and 500 mg. $\mathrm{kg}^{-1}$ of EEA. The negative control (distilled water) and solvent-control (distilled water- $25 \%$ of ethanol P.A.) groups were also included. The number of survivors in each treatment was observed in times of 5, 15, 30 minutes, 1, 2, 4, 24, 48, and 72 hours. At the end of this period, the number of survivors was counted and plotted in a graph, which the abscissa axis corresponds to the administered doses and the ordinate axis represents the survival percentage. The $\mathrm{LD}_{50}$ (dose which inactivates $50 \%$ of individuals) was estimated by the graphic and the obtained value was $200 \mathrm{mg} \cdot \mathrm{kg}^{-1}$.

\subsection{Experimental procedure (micronucleus test)}

Mutagenicity evaluation: The doses of EEA were chosen according to the determination of $\mathrm{LD}_{50}$. Five-animal groups were treated i.p. with $10 \mathrm{mg} \cdot \mathrm{kg}^{-1}\left(5 \%\right.$ of $\left.\mathrm{LD}_{50}\right)$, $20 \mathrm{mg} \cdot \mathrm{kg}^{-1}\left(10 \%\right.$ of $\left.\mathrm{LD}_{50}\right), 50 \mathrm{mg} \cdot \mathrm{kg}^{-1}\left(25 \%\right.$ of $\left.\mathrm{LD}_{50}\right)$, $100 \mathrm{mg} \cdot \mathrm{kg}^{-1}\left(50 \%\right.$ of $\left.\mathrm{LD}_{50}\right)$ and $160 \mathrm{mg} \cdot \mathrm{kg}^{-1}$ (80\% of $\mathrm{LD}_{50}$ ) of EEA for three different periods of treatment :24, 48 and 72 hour and euthanized (as recommended by MacGregor et al., (1987)). The positive control group (MMC $=4 \mathrm{mg} \cdot \mathrm{kg}^{-1}$, the maximum tolerated dose - MTD (maximum tolerated dose) - which corresponds to $80 \%$ of $\mathrm{LD}_{50}$, (Salamone et al., 1980), negative control group and solvent-control group were also included.

Antimutagenicity evaluation: Five-animal groups were co-treated i.p. with $10,20,50$ and $100 \mathrm{mg} . \mathrm{kg}^{-1}$ of EEA and 4 mg. $\mathrm{kg}^{-1}$ of MMC and sacrificed after 36 hours of treatment. The positive ( $\left.\mathrm{MMC}=4 \mathrm{mg} \cdot \mathrm{kg}^{-1}\right)$, negative and solvent-control groups were also included.

For both experiments, after the periods of treatment, femurs were exposed and sectioned opened and the bone marrow was gently flushed out using fetal calf serum. After centrifugation ( $300 \mathrm{xg}, 5$ minutes) the bone marrow cells were smeared on glass slides, coded for blind analysis, airdried and fixed in absolute methanol for 5 minutes. The smears were stained with Giemsa for detecting micronucleated polychromatic erythrocytes (MNPCE - micronucleated polychromatic erythrocytes) (Schimid, 1975). For each animal, three slides were prepared and 1000 polycromatic erythrocytes (PCE - polychromatic erythrocytes) were counted to determine the frequency of MNPCE. To determine the cytotoxicity of this plant, 1000 normocro- matic erythrocytes (NCE - normochromatic erythrocytes) were counted, as well as the frequency of polycromatic erythrocytes within the same microscope fields. Then, the $\mathrm{PCE} / \mathrm{NCE}$ ratio was calculated. The slides were analyzed in Olympus BH-2 microcopy (10 x 100).

\subsection{Statistical analysis}

In order to analyze the mutagenic activity of the EEA, the MNPCE frequency from the treated groups was compared to the results obtained from the solventcontrol group by Student's $t$-test, with $\mathrm{p}$ value lower than $0.05(\mathrm{p}<0.05)$ considered as indicative of significance.

To analyze the antimutagenic activity of this extract, the frequency of the MNPCE from the treated groups was compared to the results obtained from the positive control group by $t$-test. p-values lower than $0.05(\mathrm{p}<0.05)$ were considered as indicative of significance.

To evaluate the cytotoxicity of the extract, PCE/NCE ratio of all treated groups was compared to the result obtained from the solvent-control in the mutagenic effect evaluation, and compared to the results obtained from the positive control in antimutagenic effect evaluation. A non-parametric test, the Sign Test was applied to determine the statistical significance of the results (Triola, 2005). The significance level considered was $p<0.01$.

\section{Results}

MNPCE frequencies and the PCE/NCE ratios at 24, 48 and 72 hours in different doses of the EEA are shown (Table 1).

For all tested doses (Table 1) (10, 20, 50, 100 and $\left.160 \mathrm{mg} . \mathrm{kg}^{-1}\right)$ in different times of evaluation (24, 48 and 72 hours) and negative control group, the results did not present a significant increase of MNPCE frequency compared to the solvent-control group $\left({ }^{\mathrm{a}} \mathrm{P}>0.05\right)$. There was significant increase of MNPCE frequency at the positive control group compared to the solvent control group ( ${ }^{\mathrm{b}} \mathrm{P}<0.05$ ). This result was in conformity to the expected value.

At 10 and $20 \mathrm{mg} \cdot \mathrm{kg}^{-1}$ of the extract, there was no significant difference of PCE/NCE ratio compared to the solvent control group ( $\left.{ }^{\mathrm{c}} \mathrm{P}>0.01\right)$ at all times evaluation. At doses of 50 and $100 \mathrm{mg} \cdot \mathrm{kg}^{-1}$, it was demonstrated a significant reduction of PCE/NCE relationship compared to the solvent control group at 24 and 48 hours ( $\left.{ }^{\mathrm{d}} \mathrm{P}<0.01\right)$. So, in these cases, cytotoxicity was verified. At 72 hours, the PCE/NCE ratio was not statistically significant compared to solvent-control group ( ${ }^{\mathrm{C}} \mathrm{P}>0.01$ ). At $160 \mathrm{mg} \cdot \mathrm{kg}^{-1}$, the relationship (PCE/NCE) was significantly lower than solvent control group in all treated times $\left({ }^{\mathrm{d}} \mathrm{P}<0.01\right)$.

In the antimutagenicity experiment, the obtained results of MNPCE frequency and PCE/NCE ratio from bone marrow by simultaneous treatment $\left(\mathrm{EEA}+4.0 \mathrm{mg} \cdot \mathrm{kg}^{-1}\right.$ of MMC) in different doses are shown (Table 2).

At $10 \mathrm{mg} \cdot \mathrm{kg}^{-1}$ of the extract and $4 \mathrm{mg} \cdot \mathrm{kg}^{-1}$ of MMC, the average for MNPCE/1000 PCE was 17.4. This result did not differ significantly from the positive con- 
Table 1. MNPCE frequencies and PCE/NCE ratios after treatment with the ethanolic extract of A. crassiflora Mart (araticum) in five animals at different doses and times.

\begin{tabular}{|c|c|c|c|c|c|}
\hline$(\%) \mathrm{DL}_{(50)}$ & $\begin{array}{c}\text { Dose of EEA } \\
\left(\mathbf{m g}^{\left.-k^{-1}\right)}\right.\end{array}$ & $\begin{array}{c}\text { Time } \\
\text { (hours) }\end{array}$ & $\begin{array}{l}\text { Individual data } \\
\text { MN/1000 PCE }\end{array}$ & $\overline{\mathbf{x}} \pm \mathbf{s}$ & PCE/NCE \\
\hline \multirow[t]{3}{*}{5} & 10 & 24 & 3-4-2-2- 2 & $2.6 \pm 0.89^{a}$ & $0.87^{\mathrm{c}}$ \\
\hline & & 48 & 2- 2- 2-3- 1 & $2.0 \pm 0.71^{\mathrm{a}}$ & $0.93^{\mathrm{c}}$ \\
\hline & & 72 & 2-1-1-2- 2 & $1.6 \pm 0.55^{\mathrm{a}}$ & $0.88^{\mathrm{c}}$ \\
\hline \multirow[t]{3}{*}{10} & 20 & 24 & 2- 2- 3-3- 2 & $2.4 \pm 0.55^{\mathrm{a}}$ & $0.97^{\mathrm{c}}$ \\
\hline & & 48 & 2-2-1-3-2 & $2.0 \pm 0.71^{\mathrm{a}}$ & $0.89^{c}$ \\
\hline & & 72 & 2- 3-2-2- 1 & $2.0 \pm 0.71^{\mathrm{a}}$ & $0.98^{c}$ \\
\hline \multirow[t]{3}{*}{25} & 50 & 24 & 5- 5- 3- 4- 2 & $3.8 \pm 1.30^{\mathrm{a}}$ & $0.61^{\mathrm{d}}$ \\
\hline & & 48 & 3-2-2-1- 1 & $1.8 \pm 0.84^{\mathrm{a}}$ & $0.48^{\mathrm{d}}$ \\
\hline & & 72 & 4- 3-1-2- 2 & $2.4 \pm 1.14^{\mathrm{a}}$ & $1.09^{\mathrm{c}}$ \\
\hline \multirow[t]{3}{*}{50} & 100 & 24 & 2- $1-3-4-2$ & $2.4 \pm 1.14^{\mathrm{a}}$ & $0.46^{\mathrm{d}}$ \\
\hline & & 48 & 4- $1-2-1-2$ & $2.0 \pm 1.22^{\mathrm{a}}$ & $0.47^{\mathrm{d}}$ \\
\hline & & 72 & 3-2-3-2- 1 & $2.2 \pm 0.84^{\mathrm{a}}$ & $1.07^{\mathrm{c}}$ \\
\hline \multirow[t]{3}{*}{80} & 160 & 24 & 3-3-2-3- 1 & $2.4 \pm 0.89^{\mathrm{a}}$ & $0.49^{\mathrm{d}}$ \\
\hline & & 48 & 3-1-3-1- 2 & $2.0 \pm 1.00^{\mathrm{a}}$ & $0.45^{\mathrm{d}}$ \\
\hline & & 72 & 2- 2- 2-1- 1 & $1.6 \pm 0.55^{\mathrm{a}}$ & $0.46^{\mathrm{d}}$ \\
\hline- & Water* & 48 & $1-2-2-1-3$ & $1.8 \pm 0.84^{\mathrm{a}}$ & $0.97^{\mathrm{c}}$ \\
\hline - & Solvent-Control** & 48 & $2-1-3-4-2$ & $2.4 \pm 1.14$ & 1.06 \\
\hline- & MMC*** & 36 & $13-18-24-25-19$ & $19.8 \pm 4.87^{\mathrm{b}}$ & $0.32^{\mathrm{d}}$ \\
\hline
\end{tabular}

${ }^{\mathrm{a}} \mathrm{P}>0.05 ;{ }^{\mathrm{b}} \mathrm{P}<0.05 ;{ }^{\mathrm{c}} \mathrm{P}>0.01 ;{ }^{\mathrm{d}} \mathrm{P}<0.01$. All the results were compared to the solvent-control group. *Negative control: distilled water; **Solvent-control: distilled water $-25 \%$ of ethanol P.A; ***Positive control: 4 mg.kg-1 of MMC.

Table 2. Frequency of MNPCE and the PCE/NCE ratio after simultaneous treatment with MMC and ethanolic extract of A. crassiflora Mart (Araticum) in five animals at different doses.

\begin{tabular}{|c|c|c|c|c|c|}
\hline$(\%) \mathrm{LD}_{(50)}$ & $\begin{array}{r}\text { Dose }\left(\mathrm{mg} \mathbf{k g}^{-1}\right) \\
(\mathrm{EEA}+\mathrm{MMC}) \\
\end{array}$ & $\begin{array}{c}\text { Time } \\
\text { (hours) }\end{array}$ & $\begin{array}{c}\text { Individual Data } \\
\text { MN/1000 PCE }\end{array}$ & $\overline{\mathbf{x}} \pm \mathbf{s}$ & PCE/NCE \\
\hline 5 & $10+4.0$ & 36 & $14-15-17-19-22$ & $17.4 \pm 3.20^{\mathrm{e}}$ & $0.33^{\mathrm{g}}$ \\
\hline 10 & $20+4.0$ & 36 & $7-8-10-11-12$ & $9.6 \pm 2.07^{\mathrm{f}}$ & $0.48^{g}$ \\
\hline 25 & $50+4.0$ & 36 & $6-8-9-9-11$ & $8.6 \pm 1.82^{f}$ & $0.26^{\mathrm{g}}$ \\
\hline 50 & $100+4.0$ & 36 & $1-1-2-3-4$ & $2.2 \pm 1.30^{f}$ & $0.13^{\mathrm{h}}$ \\
\hline- & Water* & 36 & $1-2-2-2-3$ & $2.0 \pm 0.71^{\mathrm{f}}$ & $0.98^{\mathrm{h}}$ \\
\hline- & Solvent Control** & 36 & $1-2-3-3-4$ & $2.6 \pm 1.14^{\mathrm{f}}$ & $0.96^{\mathrm{h}}$ \\
\hline- & $\mathrm{MMC}^{* * *}$ & 36 & $13-18-19-24-25$ & $19.8 \pm 4.87$ & 0.32 \\
\hline
\end{tabular}

${ }^{\mathrm{e}} \mathrm{P}>0.05 ;{ }^{\mathrm{f}} \mathrm{P}<0.05 ;{ }^{\mathrm{P}} \mathrm{P}>0.01 ;{ }^{\mathrm{h}} \mathrm{P}<0.01$. All the results were compared to the positive control group. *Negative control: distilled water; $* *$ Solvent-control: distilled water $-25 \%$ of ethanol P.A; **Positive control: 4 mg.kg-1 of MMC.

trol group $\left({ }^{\mathrm{e}} \mathrm{P}>0.05\right)$. At 20,50 and $100 \mathrm{mg} \cdot \mathrm{kg}^{-1}$ of extract co-administered with $4 \mathrm{mg} \cdot \mathrm{kg}^{-1}$ of $\mathrm{MMC}$, the averages for MNPCE were 9.6, 8.6 and 2.2, respectively. For all doses the results showed a significant reduction of MNPCE frequencies compared to the positive control group $\left({ }^{\mathrm{f}} \mathrm{P}<0.05\right)$. The negative and solvent control groups were all statistically different compared to positive control group ( $\left.{ }^{\mathrm{f}} \mathrm{P}<0.05\right)$, in agreement with the expected results.

To evaluate the cytotoxicity of this extract in the simultaneous treatment, the PCE/NCE ratio was again calculated. At 10, 20 and $50 \mathrm{mg} \cdot \mathrm{kg}^{-1}$ and $4.0 \mathrm{mg} \cdot \mathrm{kg}^{-1}$ of MMC, the results did not show any significant difference of PCE/NCE ratio compared to positive control group
( $\left.{ }^{\mathrm{P}} \mathrm{P}>0.01\right)$. At $100 \mathrm{mg} \cdot \mathrm{kg}^{-1}$ of extract and $4.0 \mathrm{mg} \cdot \mathrm{kg}^{-1}$ $\mathrm{MMC}$, a significant reduction of PCE/NCE ratio in relation to positive control $\left({ }^{\mathrm{h}} \mathrm{P}<0.01\right)$ was observed. Both negative and solvent-control groups were statistically different compared to positive control group $\left({ }^{\mathrm{h}} \mathrm{P}<0.01\right)$, which presented a lower value, in concordance with the expected result.

\section{Discussion}

The aim of this work was to evaluate the mutagenic, cytotoxic and antimutagenic activities of ethanolic extract of araticum (A. crassiflora) by mouse micronucleus test. This is a short term assay which has been widely 
employed to detect the mutagenic (clastogenic and/or aneugenic) and cytotoxic effects of substances in vivo.

Micronuclei (MN) separated from and in addition to the main nucleus of a cell are the results of acentric fragments or lagging chromosomes that fail to incorporate into either of the daughter nuclei during telophase of the mitotic cells. The frequency of $\mathrm{MN}$ in polychromatic erythrocytes (PCE) of mouse bone marrow is a very sensitive index of damage produced by ionizing radiation and by chemical mutagens (Rabello-Gay, 1991; MacGregor et al., 1987). This test presents some advantages compared to others kinds of assays, in which we may mainly mention the low cost and the reliability. In addition, this assay utilizes mammalians, which present capacity of metabolization similar to humans that hardly can be reproduced in totality in "in vitro" assays (Rabello-Gay et al., 1991). The intraperitoneal via (i.p.) was applied because this procedure maximizes the exposure of the bone marrow to chemical mutagens (Preston et al., 1981).

The results of mutagenic evaluation of EEA by bone marrow micronucleus test did not present a significant increase of MNPCE frequency compared to the solvent -control group for all tested doses in three different periods of time (24, 48 and 72 hours) (Table 1). These results indicated that EEA did not exhibit the mutagenic (clastogenic and/or aneugenic) effects in PCE of the bone marrow of mice.

The micronuclei test used in this study also detects cytotoxic effects by the PCE/NCE relationship. When normal proliferation of the bone marrow cells is affected by a toxic agent, the number of immature erythrocytes (PCE) is prejudiced in relation to mature erythrocytes (NCE). Thus, the PCE/NCE ratio may decrease (RabelloGay, 1991). Our results indicated that (Table 1), in low doses (10 and $20 \mathrm{mg} \cdot \mathrm{kg}^{-1}$ of EEA) it was not observed a significant reduction of PCE/NCE relationship at any sampling time. However, in the higher doses (50 and $100 \mathrm{mg} \cdot \mathrm{kg}^{-1}$ at 24 and 48 hours and $160 \mathrm{mg} \cdot \mathrm{kg}^{-1}$ at 24 , 48 and 72 hours) it was observed a strong cytotoxic effect, although the genotoxicity remained the same as for the solvent-control.

As the obtained results at the mutagenic assay did not exhibit a significant difference among the three different times of treatment, thus, one time of treatment was tested for antimutagenicity assay in order to reduce the number of animals in the experiment. The established time was 36 hours because at this time the positive control (MMC) presents major mutagenic action (Salamone et al., 1980).

The obtained results of the EEA co-treated with $4 \mathrm{mg} \cdot \mathrm{kg}^{-1}$ of MMC are exhibited in table 2. Our results show that at the lowest dose $\left(10 \mathrm{mg} \cdot \mathrm{kg}^{-1} \mathrm{EEA}+\right.$ $4 \mathrm{mg} \cdot \mathrm{kg}^{-1} \mathrm{MMC}$ ), the EEA did not modulate the mutagenic effect of MMC. However, the antimutagenic effect was strongly observed for all others doses tested (20, 50 e 100 mg. $\mathrm{kg}^{-1} \mathrm{EEA}+4 \mathrm{mg} \cdot \mathrm{kg}^{-1} \mathrm{MMC}$ ), diminishing, in this manner, the mutagenic activity of the alkylating agent (MMC). The cytotoxic effect in the simultaneous treatment was also evaluated. These results showed that the co-treatment, at lower doses $\left(10,20\right.$ and $50 \mathrm{mg} \cdot \mathrm{kg}^{-1}$ $\mathrm{EEA}+4 \mathrm{mg} \cdot \mathrm{kg}^{-1} \mathrm{MMC}$ ) did not differ from the cytotoxic action of MMC itself. Meanwhile, in the highest dose, the co-treatment (100 mg. $\mathrm{kg}^{-1} \mathrm{EEA}+4 \mathrm{mg} \cdot \mathrm{kg}^{-1}$ $\mathrm{MMC}$ ) caused an augmentation of cytotoxic action in relation to positive control. By these results, we can observe that, at the intermediate doses (20 and $50 \mathrm{mg} \cdot \mathrm{kg}^{-1}$ $\mathrm{EEA}+4 \mathrm{mg} \cdot \mathrm{kg}^{-1} \mathrm{MMC}$ ) of the EEA, it was exhibited an effective antimutagenic action in spite of the same magnitude of cytotoxicity in relation to MMC.

Our results were basically in concordance with earlier studies realized by various researchers on some Annona's constituents properties. A number of Annonaceae species of genus Annona have been shown to contain polyketides or ACGs with significant cytotoxic, antitumour, pesticidal, antimicrobial and antiparasitic activities (Rupprecht et al., 1990). More than 300 natural ACGs have been isolated and fully characterized from either bark, leaves and seeds of different Annonaceae species (Duret et al., 1999).

A. crassiflora Mart. extracts have previously been shown to have cytotoxicity to human lung carcinoma (A-549) and melanoma (RPMI 7951) cells (Santos et al., 1996). This activity has been associated to the ability of the ACG to inhibit ATP synthesis in the cell (Duret et al., 1999). A recent report demonstrated that ACG was able to arrest T24 bladder transitional carcinoma cells at the G1 phase and cause apoptotic cell death in a Bax- and caspase-3- related pathway (Yuan et al., 2003). According to Chiu et al. (2003), decreased intracellular cAMP and cGMP levels may also play important roles in the ACG-induced apoptosis pathway.

One common way of cytotoxicity is by free radical generation, which can lead to mutagenic effects (Bjelland and Seeberg, 2003). Probably, this mechanism may not be the unique way of action of the EEA, since no relevant DNA damage was detected. ACGs have very potent and diverse biological effects including cytotoxic, antitumor, antimalarial, pesticidal and antifeedant activities (Takada et al., 2000). We suggest that this cytotoxic activity presented by EEA could be mediated at least partly by the ACG, which could affect the ATP levels and/or induce apoptosis of the bone marrow dividing cells. However, the complexity of plant extracts cannot be overlooked, as the final response is likely to be the result of synergistic, antagonistic and other interactive effects among their biologically active components.

Another class of chemical constituents of this plant are the flavonoids, which have important effects on cancer chemoprevention and therapy. Santos and Salantino (2000) studied foliar flavonoids of Annonaceae and reported the presence of kaempferol and quercetin (flavonols) in A. crassiflora. A great number of scientists reported that some flavonoids have antimutagenic and anticarcinogenic activities against a number of genotoxic agents (Santos and Salantino, 2000; Galati and O'Brien, 
2004). Ündeger et al. (2004) reported that quercetin was able to reduce significantly the DNA strand breakage induced by MMC in human lymphocytes. In addition, kaempferol and quercetin were able to inhibit hemolysis, lipid peroxidation and superoxide radical generation, exerting a potent antioxidant activity ( $\mathrm{Ng}$ et al., 2003). Although how quercetin and other flavonoids protect against DNA damage and potentially against carcinogenesis is largely unknown, it is suggested that flavonoids may act as antioxidant, free radical scavengers, inhibitors of tumor cell growth, inducers of apoptosis, modulators of DNA repair or carcinogen inactivators (Lee et al., 2003; Duthie and Dobson, 1999).

The EEA exhibited in this study, antimutagenic effects. Probably, the antimutagenic activity detected in our experiment might be mediated at least partly by the action of flavonoids. Since many active chemicals possess a biphasic nature (with antimutagenic and mutagenic effects) (Zeiger, 2003) for this extract, the mutagenic action was not presented.

In summary, ours results indicate that the ethanolic extract of araticum (EEA) did not exhibit mutagenic effect in mice. The cytotoxicity was evidenced specially for higher doses. The antimutagenic effect of this plant towards MMC was strongly demonstrated. Possibly, the antimutagenic activity exhibited might contribute to an anticarcinogenic effect and the cytotoxicity to an antitumoral activity. However, further studies are required to better characterize the antimutagenic activity of $A$. crassiflora Mart. extract and to identify their active compounds and mode of action.

Acknowledgments - This study was supported with grants from Conselho Nacional de Desenvolvimento Científico e Tecnológico (CNPq, Brazil) and Fundação de Apoio à Pesquisa de Goiás. The authors thank to Professor Heleno Dias Ferreira, from the Departamento de Biologia Geral da UFG, who identified the plant material.

\section{References}

ALADE, PI. and IROBI, ON., 1993. Antimicrobial activities of crude extracts of Acalypha wilkesinana. J. of Ethnopharmacology, vol. 39, no. 3, p. 171-174.

ALALI, FQ., LIU, XX. and McLAUGHLIN, JL., 1999. Annonaceous acetogenins: recent progress. J. Nat. Prod., vol. 62 , no. 3, p. 504-540.

ALMEIDA, SP., SILVA, JA. and RIBEIRO, JF., 1987. Aproveitamento Alimentar de espécies nativas dos cerrados: araticum, barú, cagaita e jatobá, EMBRAPA-CPAC, Planaltina, first ed., 83 p.

ANDRADE, LS., SENA, JS., COSTA, PM. and CHEN-CHEN, L., 2004. Efeito antimutagênico do extrato de Stryphnodendron adstringens Mart. (barbatimão) em camundongos. Anais do $50^{\circ}$ Congresso Brasileiro de Genética, Santa Catarina, Brazil.

BJELLAND, S. and SEEBERG, E., 2003. Mutagenicity, toxicity and repair of DNA base damage induced by oxidation, Mutat. Res., vol. 531, no. 1-2, p. 37-80.
CASTRO, DB., SANTOS, DB., FERREIRA, HD., SANTOS, SC. and CHEN-CHEN, L., 2004, Atividades mutagênica e citotóxica de Cochlospermum regium Mart. (algodãozinho-docampo) em camundongos. Rev. Bras. Pl. Med., vol. 6, no. 3, p. 15-19.

CHIU, HF., CHIH, TT., HSIAN, YM., TSENG, CH., WU, MJ. and WU, YC., 2003. Bullatacin, a potent antitumor Annonaceous acetogenin, induces apoptosis through a reduction of intracellular pathway cAMP and cGMP levels in human hepatoma 2.2.15 cells, Biochem. Pharmacology, vol. 65, no. 3, p. 319-327.

CORREIA, MP., 1926. Dicionário das plantas úteis e espécies exóticas, Ministério da Agricultura, Rio de Janeiro, vol I, $747 \mathrm{p}$.

CRUZ, GL., 1979. Dicionário das plantas úteis do Brasil, Ed. Civilização Brasileira S.A, Rio de Janeiro, 599 p.

DURET, P., HOCQUEMILLER, R., GANTIER, J.C. and FIGADEÈRE, B., 1999. Semisynthesis and Cytotoxicity of Amino Acetogenins and Derivativesy, Bioorg. Med. Chem., vol. 7, no. 9, p. 1821-1826.

DUTHIE, SJ. and DOBSON, VL., 1999. Dietary flavonoids protect human colonocyte DNA from oxidative attack in vitro. Eur. J. Nutr., vol. 38, no. 1, p. 28-34.

FONSECA, CAS., LEAL, J., COSTA, SS. and LEITÃO, AC., 1994. Genotoxic and mutagenic effects of guarana (Paullinia cupana) in prokaryotic organisms. Mutat. Res., vol. 321, no. 3, p. $165-173$.

GALATI, G. and O'BRIEN, PJ., 2004. Potential toxicity of flavonoids and other dietary phenolics: significance for their chemopreventive and anticancer properties. Free Radical Biol. Med., vol. 37, no. 3, p. 287-303.

GONZÁLEZ, MC., LAVAUD, C., GALLARDO, T., ZAFRAPOLLO, MC. and CORTES, D., 1998. New Method for the determination of the absolute Stereochemistry in Antitumoral Annonaceous Acetogenins. Tetrahedron, vol. 54, no. 22, p. 6079-6088.

GRAHAM, JG., QUINN, ML., FABRICANT, DS. and FARNSWORTH, NR., 2000. Plants used against cancer - an extension of the work of Jonathan Hartwell. $J$. of Ethnopharmacology, vol. 73, no. 3, p. 347-377.

HEDDLE, JA., 1973. A rapid in vivo test for chromosomal damage, Mutat. Res., vol. 18, no. 2, p. 187-190.

LEE, JC., KIM, J., PARK, JK., CHUNG, GH. and JANG, YS., 2003. The antioxidant, rather than prooxidant, activities of quercetin on normal cells: quercetin protects mouse thymocytes from glucose oxidase-mediated apoptosis. Experim. Cell Research, vol. 291, no. 2, p. 386-397.

MacGREGOR, JT., HEDDLE, J.A., HITE, M., MARGOLIN, BH., RAMEL, C., SALAMONE, MF., TICE, RR. and WILD, D., 1987. Guidelines for the conduct of micronucleus assay in mammalian bone marrow erythrocytes. Mutat. Res., vol. 189, no. 2, p. 103-112.

MARQUES, RCP., MEDEIROS, SRB., DIAS, CS., BARBOSAFILHO, JM. and AGNEZ-LIMA, LF., 2003. Evaluation of the mutagenic potential of yangambin and of the hydroalcoholic extract of Ocotea duckei by the Ames test. Mutat. Res., vol. 536, no. 1-2, p. 117-120.

NG, TB., LIU, F., LU, Y., CHENG, CHK. and WANG, Z., 2003. Antioxidant activity of compounds from the medicinal herb 
Aster tataricus. Comparative Biochem. Phys. Part C 136 no. 2, p. 109-115.

PRESTON, RJ., BENDER, MA., BREWEN, JG., CARRANO, AV., HEDDLE, JA., MACFEE, AF., WOLFF, S. and WASSON, JS., 1981. Mammalian in vivo and in vitro cytogenetic assays. A report of the U.S. EPA's Gene Tox Program. Mutat Res., vol. 87 no. 2, p. 143-188.

RABELLO-GAY, MN., 1991. Teste do Micronúcleo em Medula Óssea. In: Mutagênese, teratogênese e carcinogênese: métodos e critérios de avaliação, Ed. SBG, Ribeirão Preto, 246 p.

RAMOS, A., EDREIRA, A., VIZOSO, A., BETANCOURT, J., LO'PEZ, M. and DE'CALO, M., 1998. Genotoxicity of an extract of Calendula officinalis L.. J. of Ethnopharmacology, vol. 61 , no. 1 , p. 49-55.

RIBEIRO, LR. and SALVATORI, DMF., 2003. Dietary components may prevent mutation-related diseases in humans. Mutat. Res., vol. 544, no. 2-3, p. 195-201.

RIZZO, JA., FONSECA, AS., VALVA, FD., COELHO, ASG., SILVA, MJ. and VIANA, MVL., 1996. Ecogenética de Harconiaspeciosa Gómez. I- Padrão espacial de distribuição espacial de $H$. speciosa var gardneri e var pubescens. Anais do XLVII Congresso Nacional de Botânica, Rio de Janeiro, Brasil.

RUPPRECHT, JK., HUI, YH., MCLAUGHLIN, JL., 1990. Acetogenins from Annonaceae. J. Nat. Prod., vol. 53, no. 2, p. 237.

SALAMONE, MF., HEDDLE, JA., STUART, E. and KATZ, M., 1980. Towards an improved micronucleus test: Studies on 3 models agents: mitomycin C, cyclophosphamide and dimethylbenzanthracene. Mutat. Res., vol. 74, no. 5, p. 347-356.

SANTOS, DYAC. and SALANTINO, MLF., 2000. Foliar flavonoids of Annonaceae from Brazil: taxonomic significance. Phytochemistry, vol. 55, no. 6, p. 567-573.

SANTOS, PL., BOAVENTURA, MAD., SUN, NJ., CASSADY, MJ. and OLIVEIRA, AB., 1996. Araticunlin, a bis-tetrahydrofuran polyketide from Annona crassiflora Mart.. Phytochemistry, vol. 42, no. 3, p. 705-707.

SCHIMID, W., 1975. The micronucleus test. Mutat. Res., vol. 31 , no. 1 , p. 9-15.
SERPELONI, JM., DALIO, RJD., SANTOS, FV., BERNARDI, CC., MESQUITA, SFP., MACIEL, MAM., PINTO, AC., FARIA, MJSS. and CÓLUS, IMS., 2004. Efeitos antimutagênicos e ausência de mutagenicidade do extrato metanólico de Cróton cajucara em células somáticas de camundongos submetidos a tratamento subcrônico. Anais do $50^{\circ}$ Congresso Brasileiro de Genética, Santa Catarina, Brazil.

STEPP, JR., 2004. The role of weeds as sources of pharmaceuticals. J. of Ethnopharmacology, vol. 92, no. 2-3, p. 163-166.

TAKADA, M., KUWABARA, K., NAKATO, H., TANAKA, A., IWAMURA, H. and MIYOSHI, H., 2000. Definition of crucial structural factors of acetogenins, potent inhibitors of mitochondrial complex I. $B B A$, vol. 1460 , no. $2-3$, p. 302-310.

TORMO, JR., GALLARDO, T., ARAGON, R., CORTES, D. and ESTORNELL, E., 1999. Specific interactions of monotetrahydrofuranic annonaceous acetogenins as inhibitors of mitochondrial Complex I. Chem. Biol. Interact., vol. 122, no. 3, p. 171-183.

TRIOLA, MF., 2005. Estatística Não-Paramétrica. In Introdução à Estatística, ed. LTC, Rio de Janeiro, 682 p.

ÜNDEGER, U., AYDÝN, S., BASARAN, AA. and BASARAN, NS., 2004. The modulating effects of quercetin and rutin on the mitomycin C induced DNA damage. Toxicol. Lett., vol. 151, no. 1 , p. 143-149.

VERSCHAEVE, L., KESTENS, V., TAYLOR, JLS., ELGORASHI, EE., MAES, A., VAN PUYVELDE, L., de KIMPE, N. and VAN STADEN, J., 2004. Investigation of the antimutagenic effects of selected South African medicinal plant extracts. Toxicol. in Vitro, vol. 18, no. 1, p. 29-35.

YUAN, SSF., CHANG, HL, CHEN, HW., YEH, YT., KAO, YH., LIN, KH., WU, YC. and SU, JH., 2003. Annonacin, a mono-tetrahydrofuran acetogenin, arrests cancer cells at the G1 phase and causes cytotoxicity in a Bax- and caspase-3-related pathway. Life Sci., vol. 72, no. 25, p. 2853-2861.

ZEIGER, E., 2003. Illusions of safety: antimutagens can be mutagens, and anticarcinogens can be carcinogens. Mutat. Res., vol. 543, no. 3, p. 191-194. 
